\title{
CLEARWATER HERITAGE
}

TIM E.H. JONES, Box 101, Dalmeny, Saskatchewan, SOK 1 E0 and HENRY T. EPP, 714 Delaronde Crescent, Saskatoon, Saskatchewan. S7J $3 Z 8$

The Clearwater River arises in the Northern Coniferous Forest vegetation region of the Precambrian Shield, about halfway between Athabasca and Peter Pond lakes in northwestern Saskatchewan. It flows southeast for about half of its 280 kilometer course through Saskatchewan, but then turns abruptly southwest near Careen Lake and enters the Athabasca River at Fort McMurray in Alberta, and its waters eventually reach the great MacKenzie River and Arctic Ocean.

As its name (correctly) implies, it is an increasingly rare phenomenon in the modern world, a very clear stream. Its character and environs vary considerably, depending on the underlying geology, as it flows through three zones of distinctively different bedrock:
Precambrian granites and sandstones, and Devonian limestones. The nature and erosional resistence of the geology, the presence of local topographic relief of some $200 \mathrm{~m}$ and a vertical drop of over $150 \mathrm{~m}$ as the river flows from its Broach Lake headwaters to the Athabasca combine to give an outstanding and, at times, spectacular canoeing experience, as the river flows over rocky ledges, boulderstrewn rapids or through quiet, meandering stretches. There are a number of landform features which make travelling on the Clearwater a most attractive nature experience, including small gorges, waterfalls, sinkholes, a very deep glacial meltwater channel, a major ice-recession moraine, sandbars, outwash plains, eskers, drumlins and kames.

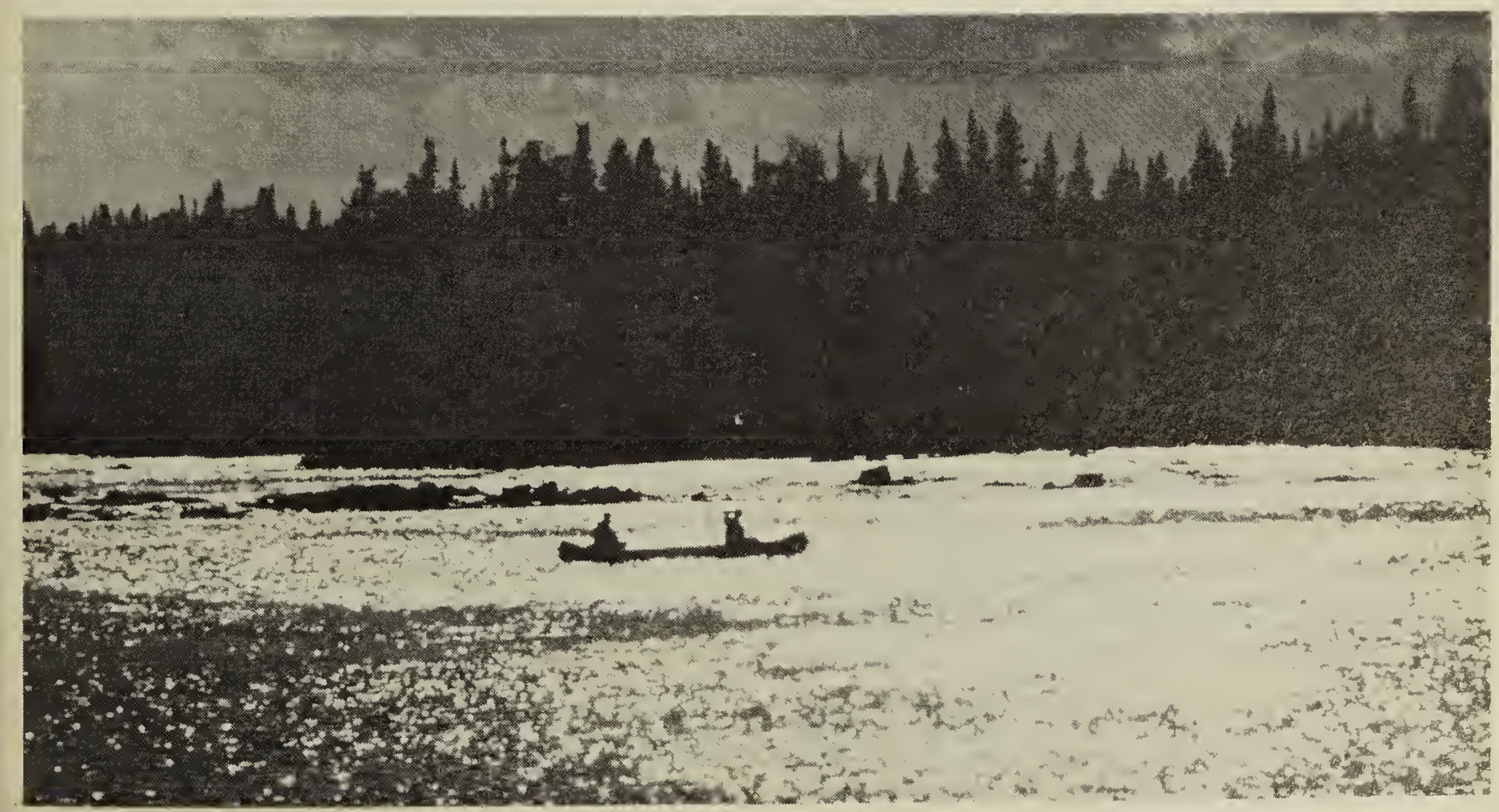

Canoeists below rapids.

R. Johnson and B. Weichel 


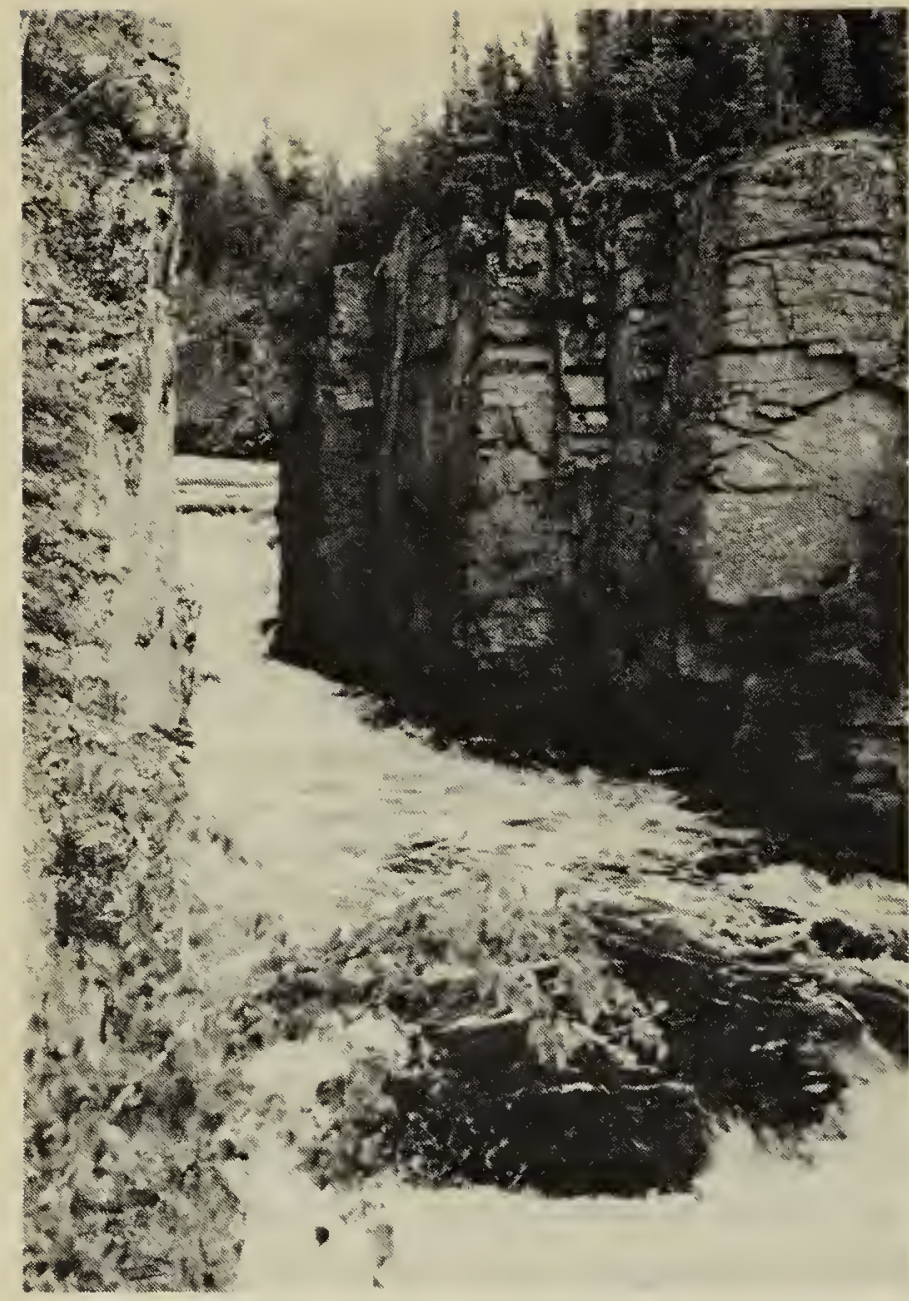

Un-named limestone gorge. R. Johnson and B. Weichel

The mantle of vegetation reflects this geomorphological variety. Both the chemical nature of the soils and the micro-climates created by the dissected topography within the subarctic climate are responsible for the rather unusual latitudinal occurrence and mixtures of arctic-subarctic and more "southerly" plants. For example, small, grassy areas are found on the south-facing slopes of the deep glacial valley in the vicinity of Methy Portage, and large stands of White Spruce and Balsam Fir are found at the northern extension of their range, in the valley. A number of rare species are known as well, although the flora of the Clearwater has not year been fully studied. Consequently, the lower Clearwater valley in Saskatchewan, especially, is a prime natural area, an example of considerable ecological variety within a relatively small space.
The fauna also has not been fully studied, although the usual northern boreal forest mammals like moose, bear, woodland caribou and smaller furbearers like wolverine, mink, muskrat and beaver are known. The Clearwater is one of the world's best grayling habitats, and whitefish, pickerel and northern pike swim in the river and its tributaries like the Virgin, Mirror and Descharme. ${ }^{7}$ The birds are not described in detail yet either, but we suspect that the varied micro-habitats have attracted a rather unique mixture of types of birds.

While the Clearwater's natural attributes are now coming to be better known, ${ }^{5}$ our current knowledge of its human history, while even less complete, suggests that it is of not only provincial, but national and perhaps even international interest. It is a fact that most of the human uses of this landscape in prehistoric times and the last two hundred and ten years or so of the historic period have left few tangible traces, and that archaeological studies must therefore be undertaken to unearth evidence of human land use and the prehistoric patterns of settlement and resource exploitation. This was done on the Churchill River for the first time in the early 1970's, but such systematic surveys and excavations have yet to be done on the Clearwater. The scant current evidence from isolated finds suggests human presence here up to about 2,000 - 5,000 years ago. However, there are at least two historical features in the area of obvious interest and significance. Between Lloyd and Careen Lakes are found three small and quite time-worn rock painting sites near the northwestern periphery of the Canadian Shield rock painting style area. The well known Methy Portage, between the Clearwater River (Arctic watershed) and Lac La Loche (Hudson Bay watershed), was a crucial link for the fur traders of eastern Canada to the northwestern fur hinterland, and for the European exploitation of northwestern America. ${ }^{5}$ 
To date, it is mostly a small number of white-water canoeists who have experiences in person the natural and historical attractions of the Clearwater River itself, and a few more who have hiked the 19 kilometer long Methy Portage from Lac La Loche to the Clearwater. This is, to date, truly a wilderness area since easy access is limited to a bridge at Warner Rapids on the Cluff Lake Road.

Readers of this journal may be familiar with our late 1960 's proposal to protect the Methy Portage as a very important historical and natural area, and will recall the resolution by the S.N.H.S. at past annual meetings supporting that idea. ${ }^{2}$ Some recent initiatives by the provincial government, in cooperation with Parks Canada, give encouragement that protection and enhanced enjoyment of both the River and Portage may yet become realities.

In June, 1984, the Clearwater was nominated by Saskatchewan Parks and Renewable Resources for designation as a Canadian Heritage River. The Canadian Heritage Rivers System (C.H.R.S.) is managed by a Board made up of provincial, territorial and Parks Canada representatives. It is designed "to give national recognition to the important rivers of Canada and to ensure long-term management which will conserve their natural, historical and recreational values for the benefit and enjoyment of Canadians now and in the future." The Clearwater is the first river nominated by Saskatchewan, and one of the first four nominated by the provinces. Before C.H.R.S. status is granted, master management plans must be prepared, and Saskatchewan Parks and Renewable Resources has just received a proposed plan from consultants contracted to prepare it. ${ }^{3} 4$ The next step is to circulate the plan for public reaction and comment before officially designating the river, establishing land-use boundaries for a wilderness park and setting any other types of protective restrictions. (One possibility is naming Methy Portage a World Heritage Site under UNESCO auspices).

These are extremely encouraging developments to all lovers of wilderness, but of course in themselves they will not ensure that we and future generations will continue to enjoy such an unaltered landscape, either in person or in spirit. What will undoubtedly occur with the more official designation and recognition of the Clearwater area is increased interest in visiting it, and more pressure for better access in the form of roads. Therefore, the determination of desirable and undesirable forms of recreational activities and the various types of protection of sites and resources will be necessary. Here again is where the opinions of S.N.H.S. members will continue to be all important. Conversely, designation will have to include funded support for research to fill the many information gaps concerning the cultural and natural heritage of the area, and it should also provide some ways and means for the local Chipewyan residents to culturally and materially benefit from sensible, sensitive development of interpretation and other services.

The inauguration of the long-awaited C.H.R.S. program in Saskatchewan is potentially a giant step forward in heritage development, and it will undoubtedly stimulate the conservation of other, equally important locales. In this context, the 1978 recommendations of the Churchill River Board of Inquiry are worth remembering and repeating. The Board recommended that a "Churchill Heritage Waterway" be "preserved as a heritage for present and future generations", that a Waterway Commission to "establish appropriate corridor boundaries and administrative arrangements" be set up, and that local people should participate in the management of the Waterway. This Churchill Heritage Waterway would encompass the Churchill, Sturgeon-Weir and Clearwater River 


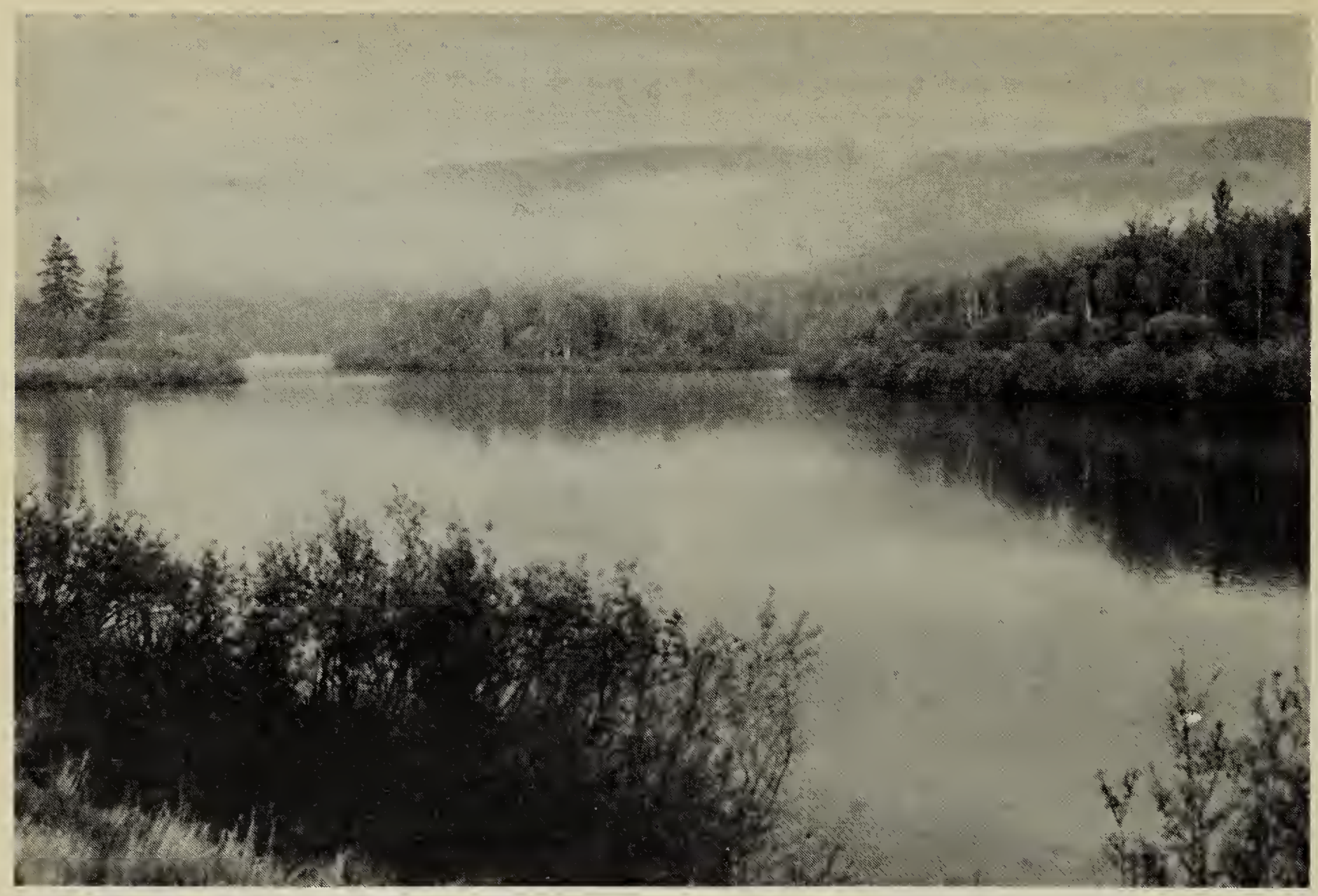

The Clearwater Valley in morning fog, near the Alberta-Saskatchewan border

R. Iohnson and B. Weichel

systems in a protected corridor not less than 32 kilometers across. ${ }^{1}$

The Churchill River Board of Inquiry carried out an exhaustive analysis of preservation versus hydro-electric development issues and held full public hearings on those issues. The overwhelming consensus was (and remains) that treasures like these major northern rivers are worth protecting and must be protected as part of our irreplaceable and irreducible natural and cultural heritage. The C.H.R.S. status for the Clearwater is, therefore, a good first step for Saskatchewan - but should not be the last.

1 CHURCHILL RIVER BOARD OF INQUIRY 1978 Report. Presented to Saskatchewan Minister of the Environment. June, $267 \mathrm{pp}$.

2 EPP, H.T. AND T. JONES 1969 The Methy Portage - Proposal for a Saskatchewan Historic and Nature Trail. The Blue Jay 27(2):101-107.
3 HILDERMAN, WITTY, CROSBY, HANNA and ASSOCIATES 1985a Clearwater River Management Plan Background Report. March, 94 pp., appendices and maps. Submitted to Parks and Lands Branch, Saskatchewan Parks and Renewable Resources.

${ }^{4}$ HILDERMAN, WITTY, CROSBY, HANNA and ASSOCIATES 1985b Clearwater River Management Plan. March, 61 pp. and maps.

5 JOHNSON, R.H. and B.J. WEICHEL 1982 Clearwater River Saskatchewan: Analysis of Canadian Heritage River and Wilderness Park Potential - Broach Lake to Alberta Border. March 62, pp. and appendices. A Pilot Study Conducted for Agreements for Recreation and Conservation (ARC) Branch, Parks Canada, and Program Planning Branch, Tourism and Renewable Resources, Saskatchewan.

${ }^{6}$ MACKINNON, C.S. 1980 Some Logistics of Portage La Loche (Methy). Prairie Forrum 5(1):51-65

7 NATIONAL AND PROVINCIAL PARKS ASSOCIATION OF CANADA 1984 The Clearwater River - Saskatchewan. Park News 20(3):19-22. 